Jurnal Health Sains: p-ISSN: 2723-4339 e-ISSN: 2548-1398

Vol. 2, No. 8, Agustus 2021

\title{
RAPID ASSESMEN MANAJEMEN INSTALASI GAWAT DARURAT RSUT PADA PANDEMI COVID-19
}

\author{
Tita Maulita Sawitri, Pujiyanto \\ Universitas Indonesia (UI) Depok Jawa Barat, Indonesia \\ Email: tita817.ts@gmail.com, pujiyanto.fkmui@gmail.com
}

\begin{tabular}{ll}
\hline INFO ARTIKEL & ABSTRAK \\
\hline Diterima & Covid-19 menyebabkan perubahan layanan terkait prosedur, fasilitas, \\
5 Agustus 2021 & tata laksana serta keselamatan pasien dan petugas dalam bekerja. RSU \\
Direvisi & Kabupaten Tangerang (RSUT) merupakan salah satu rumah sakit milik \\
15 Agustus 2021 & pemerintah yang ditunjuk untuk menyelenggarakan layanan bagi pasien \\
Disetujui & Covid-19 di seluruh lingkup layanannya. RSUT telah melakukan \\
25 Agustus 2021 & perubahan dalam manajemen pelayanan IGD, terutama pada triase \\
\hline Kata Kunci: & pasien untuk menyesuaikan perubahan pola penyakit yang ada saat ini. \\
instalasi gawat & Tujuan penelitian ini adalah untuk mengetahui rapid assesmen \\
darurat (IGD); & manajemen instalasi gawat darurat rsut pada pandemi covid-19. Tulisan \\
pandemi covid-19; & ini merupakan hasil penilaian cepat (rapid assesment) atas pengamatan \\
perubahan & pelayanan di IGD RSUT pada bulan Juni 2020, disertai wawancara \\
manajemen & kepada tim manajemen IGD dan rumah sakit. Penelitian ini merupakan \\
pelayanan; triase & studi kasus dengan melakukan rapid asesmen atas pelayanan di Instalasi \\
& $\begin{array}{l}\text { Gawat Darurat RSU Kabupaten Tangerang selama bulan Juni 2021. } \\
\text { Hasil pengamatan menunjukkan bahwa IGD RSUT telah melakukan }\end{array}$ \\
& perubahan sesuai dengan panduan kemenkes tentang pelayanan rumah \\
& sakit di masa pandemi covid-19, hanya menambahkan pemeriksaan \\
& radiologi thoraks sebagai bagian dari skrining.
\end{tabular}

\section{ABSTRACT}

Covid-19 caused changes in services related to procedures, facilities, procedures and safety of patients and officers in work. RSU Tangerang Regency (RSUT) is one of the government-owned hospitals appointed to provide services for Covid-19 patients throughout its service scope. RSUT has made changes in the management of IGD services, especially in patient triage to adjust for changes in current disease patterns. The purpose of this study is to find out the rapid assessment of emergency department management management in the covid-19 pandemic. This paper is the result of a rapid assessment of service observations at IGD RSUT in June 2020, accompanied by interviews to igd management Keywords: $\quad$ teams and hospitals. This study is a case study by conducting rapid emergency room; $\quad$ assessment of services at the Emergency Department of RSU Tangerang COVID-19 Regency during June 2021. The results of the observations showed that pandemic; change IGD RSUT had made changes in accordance with the ministry's in service guidelines on hospital services during the covid-19 pandemic, only management; triage adding thoracic radiological examinations as part of screening.

\section{Pendahuluan}

Instalasi Gawat darurat adalah instalasi pelayanan di rumah sakit yang memberikan pelayanan dalam 24 jam pertama untuk pasien dengan ancaman kematian dan kecacatan secara terpadu, dengan melibatkan

\section{How to cite:}

E-ISSN:

Published by:
Sawitri, T. M., \& Pujiyanto, P. (2021) Rapid Assesmen Manajemen Instalasi Gawat Darurat RSUT pada Pandemi Covid-19. Jurnal Health Sains 2(8). https://doi.org/10.46799/jhs.v2i8.255 $2723-6927$

Ridwan Institute 
multi disiplin ilmu dan profesi (Samah et al., 2020).

Pelayanan IGD meliputi penerimaan pasien, memilah mana kondisi pasien yang membutuhkan penanganan segera, bisa ditunda atau pasien dipulangkan. IGD juga berperan penting dalam menstabilkan kondisi pasien sebelum dipindahkan ke ruang rawat inap ataupun ruang rawat inap intensif (Intensive Care Unit/ICU). IGD juga menyediakan sarana penerimaan untuk penatalaksanaan pasien dalam keadaan bencana, hal ini merupakan bagian dari perannya di dalam membantu keadaan bencana yang terjadi di tiap daerah (DepKes, 2006).

Kualitas pelayanan tidak hanya ditentukan oleh sarana, prasarana dan SDM saja, namun juga oleh waktu tunggu pelayanan. Pasien mengharapkan pelayanan IGD diberikan dengan cepat dan akurat. Lamanya waktu tunggu di IGD akan berdampak pada hari perawatan di rawat inap yang lebih lama, mortalitas yang meningkat, dan berkurangnya kepuasan pasien (NemecLoise \& Martin, 2018; Singer et al., 2011).

Triase adalah tindakan pengelompokan pasien berdasarkan berat ringannya kasus, harapan hidup dan tingkat keberhasilan yang akan dicapai sesuai dengan standar pelayanan UGD yang dimiliki sehingga akan bisa memisahkan mana yang masuk dalam kategori true emergency atau false emergency. Menurut (Habib et al., 2016) menyatakan bahwa Triase adalah proses pengambilan keputusan yang kompleks dalam rangka menentukan pasien mana yang berisiko meninggal, mengalami kecacatan atau mengalami perburukan kondisi klinis apabila tidak mendapatkan penanganan medis dengan segera. (Kathleen Pichora-Fuller, 2008) berpendapat Triase adalah tindakan memilih atau menggolongkan semua pasien yang datang ke IGD dan menetapkan prioritas penananganan pada awalnya.
Penilaian kondisi medis triase tidak hanya melibatkan komponen topangan hidup dasar yaitu jalan nafas (Airway), pernafasan (Breathing) dan sirkulasi (Circulation) atau disebut juga $\mathrm{ABC}$ approach, tapi juga melibatkan berbagai keluhan pasien dan tanda-tanda fisik. Penilaian kondisi ini disebut dengan penilaian berdasarkan kumpulan tanda dan gejala (syndromic approach). Contoh sindrom yang lazim dijumpai di unit gawat darurat adalah nyeri perut, nyeri dada, sesak nafas, dan penurunan kesadaran. (Habib et al., 2016)

Tujuan Triase menurut (Hamarno, 2016) adalah mempercepat pemberian pertolongan, terutama pada korban dalam keadaan kritis atau emergensi sehingga nyawa korban dapat tertolong. Sedangkan menurut (Kartikawati et al., 2013) tujuan Triase adalah: 1) Mengidentifikasi kondisi yang mengancam nyawa, 2) Memprioritaskan pasien berdasarkan kondisi akut tidaknya, 3) menggali data yang lengkap mengenai data pasien

Pelayanan Rumah Sakit di Era Pandemi Covid 19 teridentifikasi di Indonesia pada tanggal 2 Maret 2020 dan jumlahnya terus meningkat sehingga Presiden Joko Widodo menetapkan bahwa Covid-19 sebagai bencana nasional pada tanggal 13 April 2020. Dengan munculnya Covid-19 menyebabkan perubahan tatanan dalam berbagai sendi kehidupan. Rumah sakit sebagai pemberi pelayanan kesehatan tingkat lanjut harus beradaptasi dalam pemberian pelayanan kesehatan di masa adaptasi kebiasaan baru yang sangat berbeda dengan keadaan sebelum COVID-19 (Kriswibowo \& Utomo, 2020). Rumah Sakit perlu menyiapkan prosedur keamanan yang lebih ketat dimana protokol PPI diikuti sesuai standar. Prosedur penerimaan pasien juga akan mengalami perubahan termasuk penggunaan masker secara universal, prosedur skrining yang lebih ketat, pengaturan jadwal kunjungan, dan pembatasan pengunjung/pendamping pasien 
bahkan pemisahan pelayanan untuk pasien COVID-19 dan non COVID-19 (Suryani \& Isnaeni, 2013).

Secara umum, prinsip utama pengaturan Rumah Sakit pada masa adaptasi kebiasaan baru untuk menyesuaikan layanan rutinnya adalah (RI, 2020):

- Memberikan layanan pada pasien COVID19 dan non COVID-19 dengan menerapkan prosedur skrining, triase dan tata laksana kasus.

- Melakukan antisipasi penularan terhadap tenaga kesehatan dan pengguna layanan dengan penerapan prosedur Pencegahan dan Pengendalian Infeksi (PPI), penerapan Keselamatan dan Kesehatan Kerja (K3) di unit kerja dan pemenuhan Alat Pelindung Diri (APD).

- Menerapkan protokol pencegahan 3M; Petugas, pengunjung dan pasien menggunakan masker, menjaga jarak antar orang $>1 \mathrm{~m}$ dan rajin mencuci tangan dengan sabun dan air mengalir selama $40 \mathrm{~s} / \mathrm{d} 60$ detik atau dengan hand sanitizer selama $20 \mathrm{~s} / \mathrm{d} 30$ detik.

- Menyediakan fasilitas perawatan terutama ruang isolasi untuk pasien kasus COVID-19.

- Terintegrasi dalam sistem penanganan COVID-19 di daerah masing-masing sehingga terbentuk sistem pelacakan kasus, penerapan mekanisme rujukan yang efektif dan pengawasan isolasi mandiri dan berkoordinasi dengan Dinas Kesehatan setempat.

- Melaksanakan kembali pelayanan esensial selama masa pandemik COVID-19.

Berdasarkan panduan teknis pelayanan rumah sakit pada masa adaptasi kebiasaan baru dari kementrian kesehatan, maka setiap petugas harus melaksanakan skrining untuk semua pasien yang masuk lewat rawat jalan atau IGD.
Di IGD, pemilahan cepat atau skrining dilakukan dengan mengukur suhu menggunakan thermal gun, kemudian perawat akan mengkaji sesuai format kementrian kesehatan. Pada prinsipnya proses triase adalah untuk mengidentifikasi pasien yang memerlukan intervensi medis segera, pasien yang dapat menunggu, atau pasien yang mungkin perlu dirujuk ke fasilitas kesehatan tertentu berdasarkan kondisi klinis pasien.

\section{Metode Penelitian}

Penelitian ini merupakan studi kasus dengan melakukan rapid asesmen atas pelayanan di Instalasi Gawat Darurat RSU Kabupaten Tangerang selama bulan Juni 2021. Data primer diperoleh dari wawancara mendalam dengan Wakil Direktur Pelayanan Medik, Koordinator Instalasi IGD, Kepala Ruangan dan perwakilan ketua tim IGD. Sedangkan data sekunder berupa dokumen seperti Kebijakan Alur Pelayanan IGD di RSU Kabupaten Tangerang; Jenis, kualifikasi, jumlah tenaga di IGD RSU Kabupaten Tangerang. Data yang diperoleh kemudian dikumpulkan, diolah dan disajikan secara deskriptif.

\section{Hasil dan Pembahasan}

\section{Instalasi Gawat Darurat RSUT}

Fasilitas yang terdapat pada Instalasi Gawat Darurat RSUT:

Ruang Triase Covid-19, Ruang Resusitasi, Ruang Tindakan, Ruang Dekontaminasi, Ruang Isolasi, IGD Sistemik, IGD Maternal, IGD Covid-19, Radiologi 24 jam, Laboratorium 24 jam, Depo Farmasi 24 jam, Ambulance 24 jam, SPGDT (Sistem Penanggulangan Gawat Darurat Terpadu).

\section{Tabel 1}

\section{Sumber Daya Manusia di IGD}


Rapid Assesmen Manajemen Instalasi Gawat Darurat RSUT pada Pandemi Covid-19

\begin{tabular}{ccccc}
\hline Jenis SDM & $\begin{array}{c}\text { Jumlah } \\
\text { (orang) }\end{array}$ & $\begin{array}{c}\text { Jumlah } \\
\text { orang/shift }\end{array}$ & $\begin{array}{c}\text { Jam } \\
\text { kerja/shift }\end{array}$ & Kompetensi \\
\hline Dokter Umum & 15 & 3 & 12 jam & $\begin{array}{c}\text { PPGD, ATLS, } \\
\text { ACLS }\end{array}$ \\
\hline Perawat & 46 & 9 & 8 jam & $\begin{array}{c}\text { BCLS, PPGD, } \\
\text { ACLS }\end{array}$ \\
\hline POS (Pembantu Orang sakit) & 13 & 3 & 8 jam & \\
\hline Administrasi & 1 & & $\begin{array}{c}8 \text { (pagi } \\
\text { saja) }\end{array}$ & - \\
\hline
\end{tabular}

2. Alur Pelayanan di IGD RSUT

Alur pelayanan pasien dimulai saat petugas melakukan triase untuk pasien yang datang ke IGD RSUT. Triase dilakukan oleh perawat terlatih yang mampu melakukan skrining dan pemilahan pasien berdasarkan kegawatdaruratannya, sekaligus untuk menilai apakah pasien terindikasi covid19. Petugas akan melakukan serangkaian pemeriksaan yaitu anamnesis, pemeriksaan fisik pasien, radiologi dan pemeriksaan laboratorium untuk menyingkirkan dignosis covid-19 kepada semua pasien yang datang ke IGD, sehingga ruangan triase sekarang dinamakan dengan 'Triase Covid-19".

Perawat yang bertugas di triase akan melakukan penilaian sesuai dengan score triase. Setelah itu petugas akan melakukan pemeriksaan untuk menyingkirkan adanya covid-19, yaitu dengan melakukan anamnesis dan pengisian skrining covid sesuai dengan ceklist. Ceklist tersebut berisi pertanyaan yang terkait dengan riwayat penyakit, perjalanan dan kontak dengan pasien Covid-19.

\section{Tabel 1}

Skrining Awal Triase Covid

Dalam 14 hari terakhir, apakah anda pernah mengalami hal hal berikut :

\begin{tabular}{|c|c|c|c|c|c|}
\hline No. & Pertanyaan & Ya & Tidak & $\begin{array}{l}\text { Jika Ya, } \\
\text { Skor }\end{array}$ & $\begin{array}{l}\text { Jika Tidak } \\
\text { Skor }\end{array}$ \\
\hline 1 & $\begin{array}{l}\text { Apakah anda atau siapapun di rumah anda saat ini } \\
\text { menderita Covid-19? }\end{array}$ & & & 5 & 0 \\
\hline 2 & $\begin{array}{l}\text { Apakah anda atau siapapun di rumah anda dalam } 14 \\
\text { hari ini sedang/pernah mengalami: } \\
\text { - Demam /suhu tubuh tinggi } \\
\text { - Batuk / piek } \\
\text { - Sesak napas / tenggorokan } \\
\text { - Sakit kepala }\end{array}$ & & & 5 & 0 \\
\hline 3 & $\begin{array}{l}\text { Apakah anda atau siapapun di rumah anda memiliki } \\
\text { riwayat kontak erat dengan orang yang dinyatakan } \\
\text { probabel, suspek atau confirm covid-19? berjabat } \\
\text { tangan, berbicara dekat, berada dalam satu ruangan } \\
\text { /satu rumah) }\end{array}$ & & & 5 & 0 \\
\hline 4 & $\begin{array}{l}\text { Apakah anda atau siapapun di rumah anda pernah } \\
\text { keluar rumah / tempat umum (pasar, fasyankes, } \\
\text { kerumunan orang, dan lain-lain? }\end{array}$ & & & 1 & 0 \\
\hline 5 & $\begin{array}{l}\text { Apakah anda atau siapapun di rumah anda pernah } \\
\text { melakukan perjalanan ke luar kota /ke luar negeri? } \\
\text { (wilayah yang terjangkit /zona merah). }\end{array}$ & & & 1 & 0 \\
\hline 6 & $\begin{array}{l}\text { Apakah anda atau siapapun di rumah anda pernah } \\
\text { mengikuti kegiatan yang melibatkan banyak orang? }\end{array}$ & & & 1 & 0 \\
\hline 7 & $\begin{array}{l}\text { Apakah anda atau siapapun di rumah anda pernah } \\
\text { menggunakan transportasi umum? }\end{array}$ & & & 1 & 0 \\
\hline \multicolumn{6}{|c|}{ Total Skor } \\
\hline \multicolumn{6}{|c|}{ Keterangan : } \\
\hline & $0=$ resiko rendah & & & - & tinggi \\
\hline
\end{tabular}


Setelah dilakukan anamnesis dan pemeriksaan fisik, akan dilakukan pemeriksaan laboratorium swab antigen Covid-19 dan pemeriksaan darah berupa pemeriksaan darah perifer lengkap (Hemoglobin, lekosit, hematokrit, Trombosit, dan hitung jenis), diluar pemeriksaan kimia darah lain yang sekiranya diperlukan unuk menunjang diagnosis pasien. Dokter IGD akan melakukan penilaian setelah keluar hasil laboratorium dan rontgen thorax, dan mengkonsulkan hasil pemeriksaan tersebut ke dokter spesialis paru. Sesuai hasil penilaian dokter Spesialis Paru, pasien kemudian diputuskan masuk ke ruangan IGD Covid atau IGD Non Covid (Bagan 1).

\section{Bagan 1 \\ Alur di Triase Covid-19 RSUT}

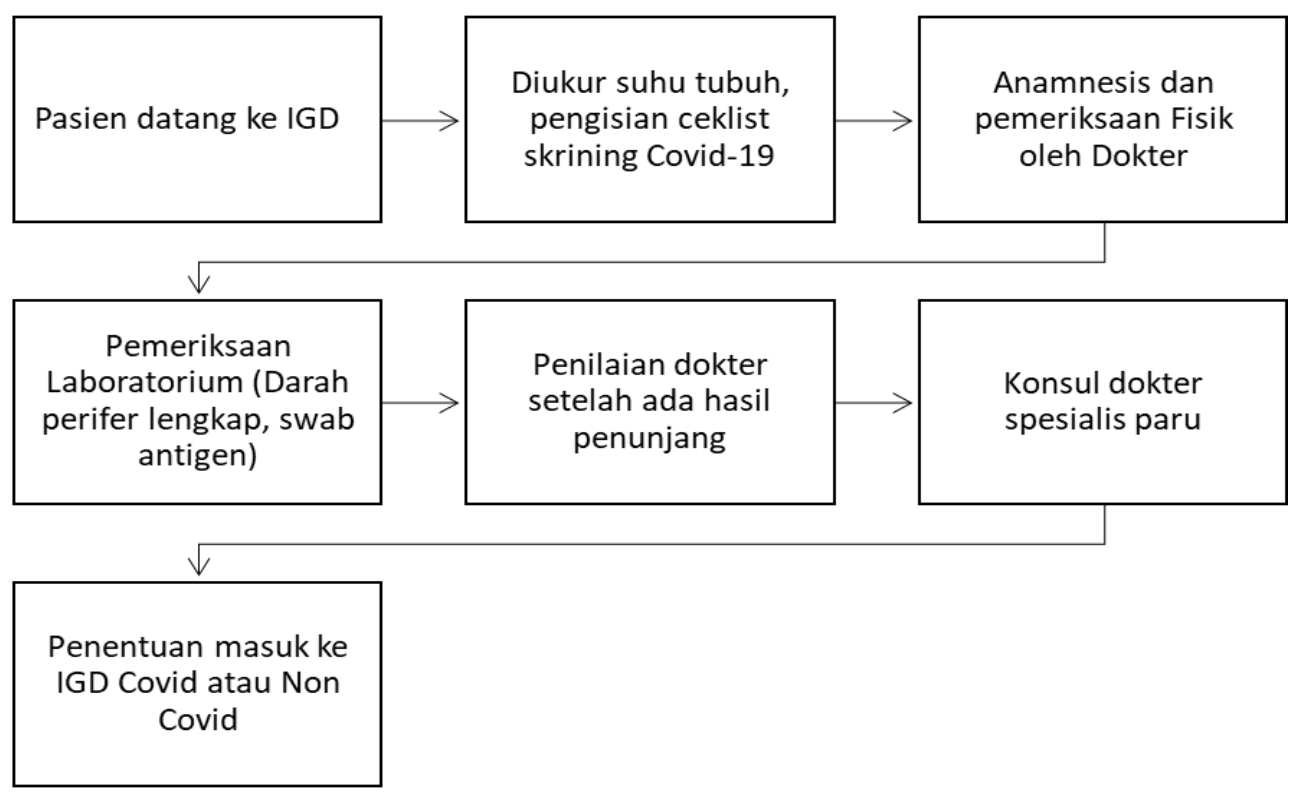

Apabila pasien yang datang membawa hasil swab antigen atau PCR covid-19 dengan hasil negatif, akan diarahkan langsung ke IGD non Covid/IGD sistemik.

Saat pasien terindikasi menderita covid-19, maka dokter akan menilai apakah pasien bisa menjalani rawat jalan dan melakukan isolasi mandiri, perlu dirawat di rumah sakit, atau memerlukan perawatan intensif di ICU khusus covid-19. Apabila mendapat ruang rawat maka pasien akan menjalani tata laksana dan pemberian terapi sesuai kondisi pasien.
Apabila hasil pemeriksaan tidak menunjukkan indikasi covid-19, maka pasien diarahkan ke IGD sistemik. Di sana baru akan dilakukan pemeriksaan lebih lanjut untuk menentukan diagnosis dan terapi yang lebih terarah. Ruang di IGD sistemik terbagi atas ruang IGD maternal, bedah atau tindakan, neonatal, medical dan ruang resusitasi. Pasien selanjutnya diputuskan untuk bisa dipulangkan, dirawat inap, menjalani tindakan operasi, atau dirujuk ke rumah sakit lain. Apabila pasien dirawat inap, maka dokter IGD akan melakukan konsultasi 


\section{Bagan 2}

\section{Alur Pasca Triase Covid-19}

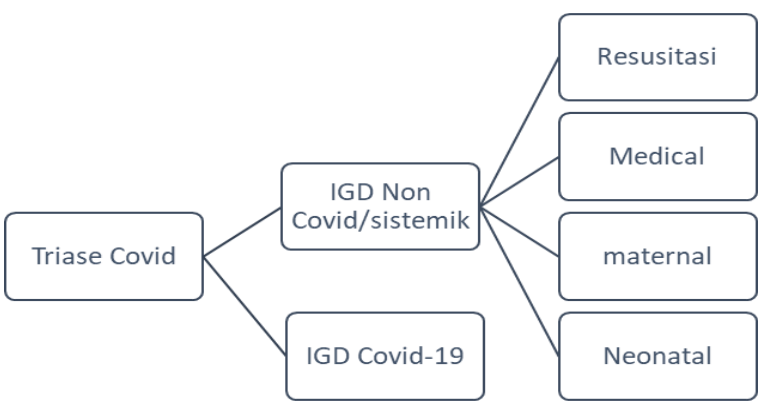

Identifikasi masalah dilakukan dengan cara membandingkan kesenjangan antara apa yang diharapkan (expected) dengan apa yang telah terjadi (observed).

Penyebab masalah dapat timbul dari bagian input maupun proses. Input merupakan sumber daya atau masukan oleh sesuatu. Sumber daya yang dimaksud dalam hal ini terdiri dari:

a. Man

Man yang dimaksud adalah sumber daya manusia (SDM) yang dapat dilihat dari jumlah staf atau petugas, keterampilan, pengetahuan, dan motivasi kerja yang dimiliki oleh petugas. Semua tenaga kesehatan di IGD RSU Kabupaten minimal memiliki sertifikat PPGD, BLS, ACLS atau ATLS sehingga secara kualifikasi sudah sesuai.

Dokter di IGD Rumah sakit Umum Kabupaten Tangerang berjumlah 15 orang, bersifat closed unit yang berarti hanya bertugas di IGD saja (tidak bertugas ke rawat inap). Jam kerja dokter IGD selama 12 jam per shift, 1 shift terdiri dari 3 orang dokter. Dalam 1 shift setiap dokter akan bertugas di ruang triase covid selama 4 jam, dan sisanya di

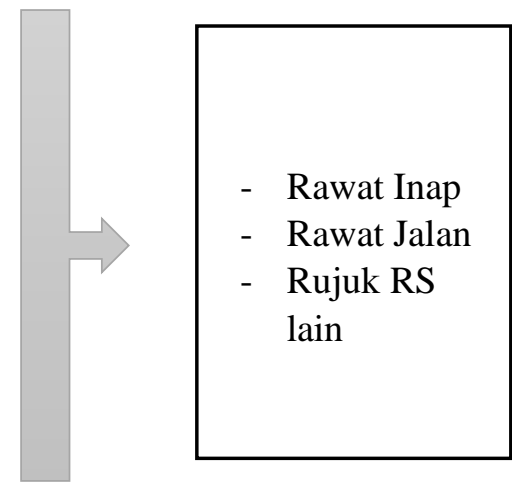

ruang triase sistemik. 2 orang yang betugas di triase sistemik bisa mengatur waktu istirahat sesuai dengan keadaan pasien di IGD. Dokter umum akan bertugas 13-14 kali dalam 1 bulan.

Apabila melihat jam kerja dokter umum di IGD, terlihat bahwa jam kerja dokter umum per kali tugas melebihi jam kerja yang ditentukan dari Undang-Undang Nomor 13 tahun 2003 tentang ketenagakerjaan, pasal 77 ayat 2 yang menyatakan bahwa waktu kerja yang dimaksud dalam ayat (1) meliputi: a. Tujuh jam dalam satu hari dan empat puluh jam dalam satu minggu untuk enam hari kerja dalam satu minggu; atau b. delapan jam dalam satu hari dan empat puluh jam dalam 1 satu minggu untuk lima hari kerja dalam satu minggu. Akan tetapi hal ini tidak berlaku untuk sektor tertentu, dan bila sudah disepakati oleh kedua belah pihak. Secara kumulatif, waktu kerja dokter umum IGD berkisar antara 156-168 jam per bulan, sehingga jumlah demikian dirasakan tidak menyalahi peraturan Disnaker (Maringan, 2015). 
Perawat IGD RSUT sebanyak 46 orang, dengan jumlah perawat per shift sebanyak 9 orang. Perawat memiliki mobilitas dalam menjalankan tugasnya. Perawat yang bertugas di triase covid sebanyak minimal 3 orang, namun bila diperlukan, perawat di IGD sistemik bisa pindah ke triase covid. Dengan rata-rata kunjungan 20-40 pasien per hari di masa pandemi covid, staf yang bertugas telah memiliki jumlah yang seimbang dengan jumlah pasien, jenis pekerjaannya dan keterampilan petugas.

Dari pengukuran jam kerja dan jumlah SDM tenaga kesehatan, dapat dilihat bahwa jumlah SDM di IGD RSUT sudah sesuai. Namun perlu dipertimbangkan mengenai panjangnya jam kerja dokter, karena waktu kerja yang terlalu lama dapat menyebabkan kelelahan dan kesalahan individu meningkat. Namun terdapat studi menyatakan bahwa seiring waktu tim dapat mengkompensasi kesalahan ini, sehingga mereka yang bekerja bersama dalam periode yang lebih lama memiliki skor kesalahan individu yang lebih tinggi tetapi skor kesalahan tim lebih rendah daripada mereka yang bekerja bersama hanya sebentar. Sehingga tampaknya faktor-faktor seperti dukungan rekan kerja dan pimpinan, kerja tim yang baik memberikan outcome yang lebih baik dibandingkan jam kerja yang diperpendek (Cozens et al., 2004).

b. Money

Money diartikan sebagai jumlah dana yang tersedia. Dalam hal ini, RSUT merupakan rumah sakit milik Pemerintah Daerah
Kabupaten Tangerang dengan status

BLUD, sehingga memiliki kemampuan untuk mengelola keuangan sendiri dan tidak tergantung dari pembiayaan Pemda saja. Untuk pembiayaan pasien covid-19 di klaim ke pemerintah pusat lewat mekanisme klaim pembiayaan pasien covid-19.

c. Material

Material adalah jumlah peralatan yang tersedia untuk menjalankan pelayanan. Selama pandemi covid manajemen telah menyiapkan berbagai upaya agar pelayanan pasien dapat berjalan dengan baik, dengan menjaga keselamatan pasien dan petugas. Manajemen menyiapkan alat pelindung diri level 3 untuk tenaga kesehatan di ruang triase covid, ruang IGD isolasi covid-19, maupun petugas laboratorium dan radiologi yang kontak dengan pasien. Untuk petugas di IGD non-Covid disiapkan APD level 2. APD yang disiapkan dalam jumlah memadai.

Pada Standar Prosedur Operasional baru, ruangan triase covid adalah ruangan yang dahulu difungsikan sebagai ruangan IGD lama, dengan kapasitas tempat tidur pasien di ruang triase covid maksimal 20 orang. Apabila pasien lama menunggu hasil pemeriksaan penunjang, akan terjadi penumpukan di ruangan triase sehingga standar jumlah orang dalam 1 ruangan dan jarak minimal tidak terpenuhi.

Untuk penyediaan oksigen, terdapat 9 titik oksigen yang tertanam di dinding, namun bila dibutuhkan, pasien dapat diberikan oksigen yang berasal dari tabung oksigen yang tersedia di IGD. 
Ruang Triase covid dilengkapi dengan 2 monitor mobile, sehingga bisa digunakan untuk pasien dengan kondisi berat yang memerlukan pemantauan ketat menggunakan monitor untuk mengukur tanda vital pasien. Ruangan triase covid memiiliki 2 alat optiflow, namun belum tersedia ventilator mobile. Ventilator tersedia 1 buah di ruangan IGD sistemik.

Sarana dan prasarana lain telah disiapkan dan berdasarkan pengamatan residen dalam jumlah dan kapasitas cukup.

d. Method

Method
mekanisme atau cara yang
digunakan untuk menjalankan
sebuah program atau pelayanan.
Terdapat tambahan pemeriksaan
dalam Metode yang dipergunakan
oleh IGD RSUT dari Panduan
Teknis Pelayanan Di Rumah Sakit Selama Masa Adaptasi Kebiasaan Baru yang dikeluarkan oleh Kementrian kesehatan RI. Dalam panduan Kemenkes, triase dilakukan dengan melakukan penilaian cepat di 2 komponen, pada (1) anamnesis dalam 14 hari terdapat riwayat bepergian keluar kota atau kontak dengan pasien terkonfirmasi, adanya gejala demam, batuk, pilek atau nyeri tenggorokan, hasil pemeriksaan PCR, serta adanya gejala klinis ditemukan suhu >380 C dan (2) adanya gejala klinis sesak napas dengan adanya peningkatan upaya dan frekuensi napas. Apabila skor nya 0 maka pasien bisa melanjutkan ke pelayanan non covid, namun bila skor 1-3 harus masuk ke IGD Covid-19. Di IGD RSUT, semua pasien diperlakukan sama, yaitu harus melalui skrining berupa anamnesis, pemeriksaan fisik dan penunjang laboratorium dan rontgen thorax. Semua pasien dalam kategori ATS 1-5 mendapat perlakuan sskrining yang sama. Hal ini dikecualikan pada pasien yang datang tanpa gejala klinis covid-19 DAN membawa hasil penunjang swab antigen non reaktif atau Swab PCR covid-19 negatif bisa langsung menuju IGD sistemik.

$$
\text { Pada pelaksanaan di }
$$

lapangan, berdasarkan hasil wawancara petugas IGD diketahui bahwa salah satu penyebab lamanya waktu tunggu pasien IGD adalah waktu yang dibutuhkan untuk melakukan pemeriksaan radiologi dan tes swab antigen covid-19. Petugas radiologi akan mengumpulkan sedikitnya 4-6 pasien untuk melakukan pemeriksaan rontgen thoraks. Sedangkan untuk pengambilan swab antigen harus menunggu kedatangan analis lab dan menunggu hasil swab antigen minimal selama 2 jam. Dengan metode yang digunakan ini menyebabkan adanya penumpukan di triase covid-19 (Bottle neck effect) karena semua pasien harus menunggu hasil pemeriksaan radiologi dan laborarorium.

Sedangkan proses terdiri dari:

a. Planning

Planning atau perencanaan adalah sebuah proses yang dimulai dengan merumuskan tujuan organisasi, sampai dengan menetapkan alternatif kegiatan untuk mencapainya.

SPO yang ditetapkan oleh IGD RSUT bermula sejak bulan Maret 2020, saat itu mulai terdapat 
pasien Covid-19 di Indonesia. Kabupaten Tangerang yang merupakan daerah penyangga DKI Jakarta merupakan daerah yang rentan untuk munculnya kasus covid-19. Saat itu triase dilakukan di tenda darurat, dan hingga kini akhirnya menggunakan ruangan IGD lama.

Dalam pelaksanaan pelayanan, sempat ditemukan kasus pasien dengan rapid antigen reaktif dan akhirnya terkonfirmasi covid-19 pada pasien luka bakar grade $2 b$ sebanyak $30 \%$ yang disiapkan untuk operasi debridement. Selain itu juga ditemukan pasien akut MCI dengan hasil swab antigen reaktif, sehingga akhirnya pasien menjalani terapi pemberian streptokinase di ruangan triase covid.

b. Organizing

Rangkaian kegiatan manajemen untuk menghimpun semua sumber daya yang dimiliki organisasi dan memanfaatkan secara efisien untuk mencapai tujuan organisasi.

IGD merupakan satu instalasi yang kompleks, memerlukan koordinasi dari berbagai elemen. Insatalasi lain yang terkait dengan IGD seperti instalasi radologi, laboratorium, farmasi, ketersediaan ruang rawat, konsultasi dengan spesialis, merupakan berbagai faktor yang saling berhubungan, namun apabila ada 1 yang menghambat maka akan dianggap bahwa IGD merupakan unit yang bermasalah karena keterlambatan penanganan.

c. Actuating

Proses bimbingan kepada staf agar mereka mampu berkerja secara optimal melakukan tugas pokoknya sesuai dengan keterampilan yang dimiliki dengan dukungan sumber daya yang tersedia.

d. Controlling

Proses untuk mengamati secara terus menerus pelaksanaan kegiatan sesuai dengan rencana kerja yang sudah disusun dan melakukan koreksi apabila didapatkan adanya penyimpangan. Tim IGD beserta manajemen rumah sakit senantiasa melakukan evaluasi untuk menilai apakah Spo yang saat ini berjalan memberikan hasil sesuai harapan, baik harapan pasien maupun petugas dan memberikan outcome yang baik. Hal ini terlihat dari perubahan yang dilakukan beberapa kali sejak pandemi covid dimulai hingga saat pengamatan berlangsung.

\section{Kesimpulan}

Kesimpulan dari artikel ini adalah Instalasi Gawat Darurat RSUT telah melakukan perubahan dalam menyikapi pelayanan rumah sakit pada masa pandemi covid-19. Perubahan yang dilakukan untuk meningkatkan keselamatan baik untuk pasien dan petugas.

Alur pelayanan pada masa pandemi covid di RSU Kabupaten Tangerang berupaya menemukan sejak dini pasien Covid-19 melalui pemeriksaan yang komprehensif, untuk semua pasien yang datang ke IGD RSUT.

Secara umum triase dilakukan dari anamnesis riwayat bepergian ke daerah endemis, riwayat kontak dan anamnesis gejala klinis. Selain itu dilakukan pemeriksaan swab antigen dan darah perifer lengkap.

Tim IGD dan Manajemen rumah sakit senantiasa melakukan evaluasi dan perubahan yang dirasa perlu untuk perbaikan pelayanan pasien di IGD. 
Manfaat yang dapat diperoleh dari penerapan skrining komprehensif:

Segi medis: terdeteksinya lebih dini pasien Covid-19

Segi ekonomi: membebani keuangan pasien pada kondisi pasien ringan tanpa Covid -19 namun membutuhkan penanganan di IGD, serta membebani keuangan RS untuk pasien BPJS yang tentunya perlu cost effective.

\section{BIBLIOGRAFI}

Cozens, P., Neale, R., Whitaker, J., \& Hillier, D. (2004). Tackling Crime And Fear Of Crime Whilst Waiting At Britain's Railway Stations. Google Scholar

Depkes, R. I. (2006). Pedoman Penggunaan Obat Bebas Dan Bebas Terbatas. Jakarta, Direktorat Bina Farmasi Komunitas Dan Klinik, Ditjen Bina Kefarmasian Dan Alat Kesehatan, Departemen Kesehatan Ri. Google Scholar

Habib, N., Li, Y., Heidenreich, M., Swiech, L., Avraham-Davidi, I., Trombetta, J. J., Hession, C., Zhang, F., \& Regev, A. (2016). Div-Seq: Single-Nucleus RnaSeq Reveals Dynamics Of Rare Adult Newborn Neurons. Science, 353(6302), 925-928. Google Scholar

Hamarno, R. (2016). Correlation On The Compliance Control With The Chronic Complication Among Diabetes Mellitus Type 2 At The Janti Community Health Centre Malang. Jurnal Keperawatan, 7(2). Google Scholar

Kartikawati, N. K., Naiem, M., Hardiyanto, E. B., \& Rimbawanto, A. (2013). Improvement Of Seed Orchard Management Based On Mating System Of Cajuputi Trees. Indonesian Journal Of Biotechnology, 18(1), 13-22. Google Scholar

Kathleen Pichora-Fuller, M. (2008). Use Of Supportive Context By Younger And
Older Adult Listeners: Balancing Bottom-Up And Top-Down Information Processing. International Journal of Audiology, 47(Sup2), S72-S82. Google Scholar

Kriswibowo, A., \& Utomo, S. A. P. (2020). Ekonomi Politik Indonesia Di Tengah Pandemi Covid-19. Penerbit Cakradewa Ilmu. Google Scholar

Maringan, N. (2015). Tinjauan Yuridis Pelaksanaan Pemutusan Hubungan Kerja (Phk) Secara Sepihak Oleh Perusahaan Menurut Undang-Undang No. 13 Tahun 2003 Tentang Ketenagakerjaan. Tadulako University. Google Scholar

Nemec-Loise, J., \& Martin, A. (2018). Everyday Advocacy Matters, Volume 5. Google Scholar

Ri, K. (2020). Pedoman Pencegahan Dan Pengendalian Coronavirus Disease (Covid-19)'. Kemenkes Ri, 0-115. Google Scholar

Samah, N. A., Rosli, N. A. M., Manap, A. H. A., Aziz, Y. F. A., \& Yusoff, M. M. (2020). Synthesis \& Characterization Of Ion Imprinted Polymer For Arsenic Removal From Water: A Value Addition To The Groundwater Resources. Chemical Engineering Journal, 394, 124900. Google Scholar

Singer, A. J., Thode Jr, H. C., Viccellio, P., \& Pines, J. M. (2011). The Association Between Length Of Emergency Department Boarding And Mortality. Academic Emergency Medicine, 18(12), 1324-1329. Google Scholar

Suryani, E. D., \& Isnaeni, Y. (2013). Pengaruh Pelatihan Kader Terhadap Kemampuan Melakukan Pengelolaan Posyandu Di Desa Srihandono Pundong Bantul Yogyakarta. Stikes'aisyiyah Yogyakarta. Google Scholar 
Tita Maulita Sawitri, Pujiyanto

\section{Copyright holder:}

Tita Maulita Sawitri, Pujiyanto (2021)

First publication right:

Jurnal Health Sains

This article is licensed under:

(c) (1) (2) 